\title{
Human papilloma virus (HPV) negatif verrusiform ksantom: Skrotumda nadir görülen benign tümör
}

\author{
Verruciform xanthoma with negative human papilloma virus (HPV): Rare benign \\ tumor of scrotum \\ Alev Ok Atılgan ${ }^{1} \quad$ Merih Tepeoğlu ${ }^{1} \quad$ Eda Yılmaz Akçay ${ }^{1}$ Hakan Özkardeş $^{2} \quad$ B.Handan Özdemir ${ }^{1}$ \\ ${ }^{1}$ Başkent Üniversitesi Tıp Fakültesi, Tıbbi Patoloji Anabilim Dalı, Ankara, Türkiye \\ ${ }^{2}$ Başkent Üniversitesi Tıp Fakültesi, Üroloji Anabilim Dalı, Ankara, Türkiye
}

\section{Öz}

Verrusiform ksantom oldukça nadir görülen ve genellikle oral mukozayı tutan benign bir neoplazidir. Mukoza dışında az sayıda vaka ile vulva, skrotum, penis, anal bölge ve ekstremitelerde yerleştiği bildirilmiştir. Makroskopik görünümü nedeniyle klinik olarak kondiloma aküminatum, verrüköz karsinom ve skuamöz hücreli karsinom ile karışabilir. Ayırıcı tanı için mutlaka lezyonun eksizyonu ve histopatolojik incelemesi gereklidir. Bu lezyonun etyopatogenezi hala tartışmalıdır. Literatürde HPV enfeksiyonu pozitif vakalar bildirilmiştir. Ancak HPV ile ilişkisi net açıklanamamıştır. Bu yazıda, skrotumda yerleşim gösteren bir verrusiform ksantom olgusunu, nadir görülmesi, HPV negatif olması ve klinik olarak malignite ile karışması sebebiyle sunmayı amaçladık.

Anahtar Sözcükler: Verrusiform ksantom, ksantom, verrüköz karsinom, skrotum.

\begin{abstract}
Verruciform xanthoma is a very rare benign neoplasia that usually involves the oral cavity. It was reported that arises on vulva, scrotum, penis, the anal region and the extremities with a small number of cases outside the mucosa. The macroscopic appearence of the lesion lead to a clinical misdiagnosis of condyloma accuminatum, verrucous carcinoma or squamous cell carcinoma. The excision of the lesion and histopathological examination is required for differential diagnosis. The etiopathogenesis of this lesion is still controversial. HPV positive cases was reported in the literature. But the relationship between HPV and verruciform xanthoma could not be explained. In this report, we aimed to present verruciform xanthoma of the scrotum because of its rarity, HPV negativity and mimics malign lesion, clinically.
\end{abstract}

Keywords: Verruciform xanthoma, xanthoma, verrucous carcinoma, scrotum.

\section{Giriş}

Verrusiform ksantom (VK) ilk olarak 1971 yılında Shafer tarafından tanımlanan oldukça nadir görülen mukokutanöz bir benign neoplazidir (1). Genellikle oral kavitede bukkal mukozada görülmekte olup mukoza dışında vulva, skrotum, penis, anal bölge ve ekstremitelerde yerleşen az sayıda olgu bildirilmiştir (2). VK klinikte tek, asemptomatik, yüzeyi verrüköz görünümde olan papül veya plak şeklinde karşımıza çıkar. Makroskopik görünümü nedeniyle klinik olarak malign durumlardan ayırt etmek için mutlaka lezyonun eksizyonu ve histopatolojik incelenmesi gereklidir.

Yazışma Adresi: Alev Ok Atılgan

Başkent Üniversitesi Tıp Fakültesi, Tıbbi Patoloji Anabilim Dalı, Ankara, Türkiye

Makalenin Geliş Tarihi: 07.03.2016

Kabul Tarihi: 14.04.2016
Bu nadir görülen lezyonun etyopatogenezi hala tartışmalı olmakla beraber literatürde Human Papilloma Virus (HPV) enfeksiyonu pozitif vakalar, transplantasyon sonrası immünsupresif tedavi gören hastalarda izlenen vakalar az sayıda da olsa bildirilmiştir $(1,3)$. Bu sunumda, hastanın tıbbi verilerinin yayınlanabileceğine dair aydınlatılmış onamı alınarak, skrotumda yerleşim gösteren ve HPV enfeksiyonu negatif olan bir verrusiform ksantom olgusu literatür eşliğinde tartışılarak sunulmuştur.

\section{Olgu Sunumu}

Yirmi dokuz yaşında erkek hasta, Başkent Üniversitesi Ankara Hastanesi Üroloji polikliniğine skrotumda yaklaşık olarak 7-8 yıldır var olan ve son 1 yıldır da büyüme gösteren, ağrısız, akıntılı kitle şikayeti ile başvurdu. Yapılan fizik muayenesinde hastanın sağ hemiskrotumunda saplı, papiller bir lezyonu olduğu 
görüldü. Hastanın üriner sistem yakınması, sistemik hastalığı, bilinen alerjisi ya da düzenli kullandığı ilaç yoktu. Anamnez sorgusu devam ettiğinde ise hastanın şüpheli koitus öyküsü olmadığı, 12 yıldır sigara kullandığı, eşinin sık vajinal kandida enfeksiyonu geçirdiği ve bu şikayeti nedeniyle ilk kez doktora başvurduğu öğrenildi. Yapılan rutin biyokimya tahlilinde serum glukoz, total kolesterol, trigliserid, LDL, HDL seviyeleri normal sınırlarda bulundu. Hastanın sağ hemiskrotumundaki kitle eksize edilerek hastanemiz patoloji bölümüne gönderildi. Eksize edilen doku, makroskopik olarak yaklaşık $1 \mathrm{~cm}$ uzunluğunda sapa sahip, $3 \times 2.8 \times 2 \mathrm{~cm}$ boyutunda solid kıvamlı verrüköz görünümde lezyondan ibaretti. Lezyonun tümünden hazırlanan $\mathrm{H} \& E$ boyalı kesitlerde epidermiste verruköz hiperplazi, akantoz, yer yer parakeratoz ile bazı alanlarda nötrofil lökosit infiltrasyonu izlendi (Şekil-1a). Papiller dermiste sınırlı ve papiller dermisi tümüyle dolduran çok sayıda geniş, köpüksü sitoplazmalı hücreler ile artmış kapiller damarlar görüldü (Şekil-1b). Sitolojik atipi ya da mitoz izlenmedi. Yapılan immünohistokimyasal çalışmada CD68 antikoru ile köpüksü hücrelerde yaygın boyanma izlendi ve bu hücrelerin köpüksü makrofajlar olduğu anlaşıldı (Şekil-1c). Ki 67 proliferasyon indeksi epidermis bazal tabakasında ve köpüksü histiyositlerde $\% 1$ 'in altında izlendi. Bu bulgular ile lezyonun verrusiform ksantom olduğuna karar verildi. Lezyonu oluşturabilecek nedenleri saptanmaya yönelik mantar enfeksiyonu ve HPV enfeksiyonu varlığı araştırıldı. Yapılan Periodic Acid-Schiff (PAS) histokimyası ile mantar hifa ya da sporu görülmedi. Kontrollü olarak yapılan HPV in situ hibridizasyonunda lezyonda HPV antijeni saptanmadı. Hasta 4 yıl 10 aydır lezyonun tekrarı olmadan sağlıklı yaşamına devam etmektedir.

\section{Tartışma}

Skrotumda idiyopatik kalsinozis, dermoid kist, porokeratozis, anjiyokeratom, lipom ve VK oldukça nadir görülen benign patolojilerdir. VK sıklıkla oral mukozada görülmekle beraber kadın ve erkek genital sistemi ile deride de görülebilen mukokutanöz benign neoplazidir $(2,4)$. Philipsen ve ark. (4) 2001 yılına kadar olan dünya literatürünü tarayarak yaptıkları çalışmada 282 adet oral VK olgusu ve bunun yanı sıra 46 adet skrotum derisinde VK olgusu bildirildiği tespit edilmiştir. Dünya literatüründe 2001 yılından sonra az sayıda olgu sunumları şeklinde oral ve ekstraoral VK olguları sunulmuştur.

VK makroskopik olarak verruköz, papiller ya da düz yüzeyli olarak görülebilir (5). Makroskopik görüntüleri, kondiloma aküminatum, dev molloskum kontagiyozum, seboreik keratoz, verrüköz karsinom veya skuamöz hücreli karsinom ile benzerlik göstermesinden dolayı klinik olarak karışabilirler $(2,5)$. Bu nedenle kesin tanı için, lezyonun total eksizyonu ve sonrasında mutlaka histopatolojik incelenmesi gereklidir. Histopatolojik olarak oral mukoza ve deri lezyonları benzer özelliktedir (6).
Histopatolojik incelemede epidermiste verrüköz hiperplazi, akantoz, hiperkeratoz, parakeratoz ve en karakteristik bulgu olarak papiller dermiste CD68 antikoru pozitif köpüksü makrofajlar görülmektedir $(1,2,6)$.
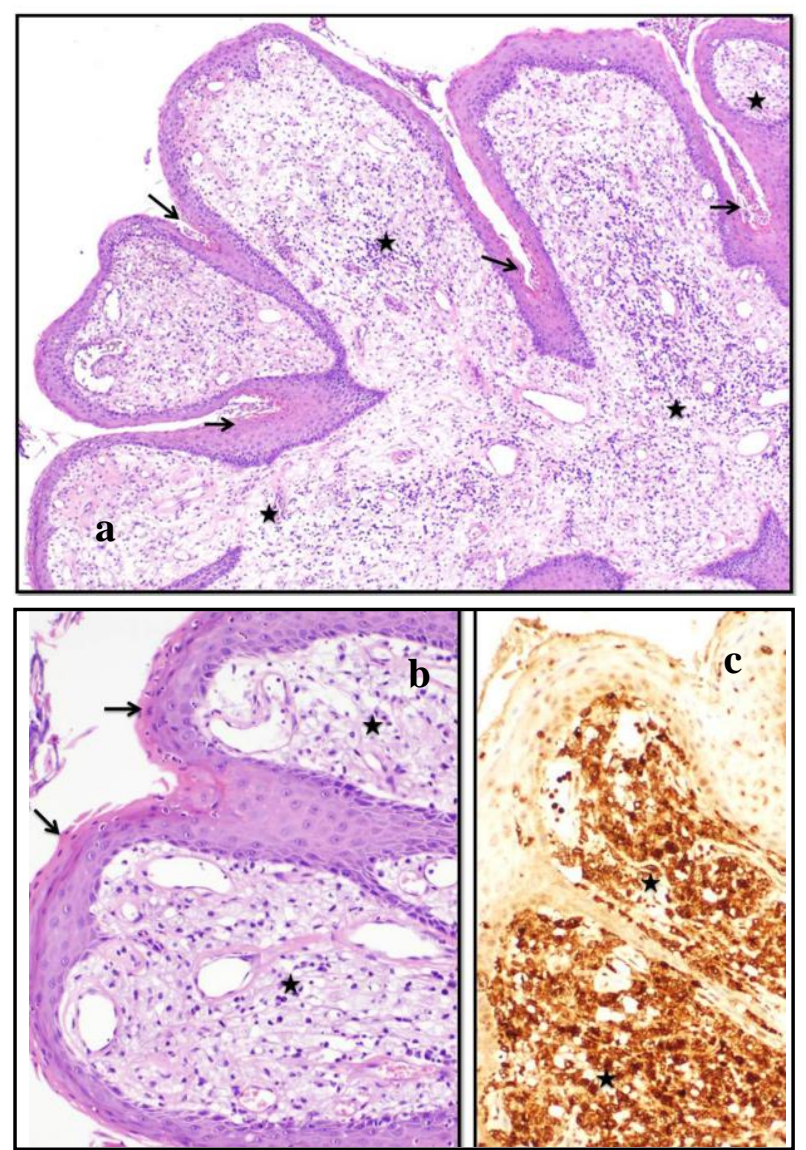

Şekil-1. a. Papiller konfigürasyon gösteren verrusiform ksantom (Epidermiste hiperkeratoz, parakeratoz alanları ok ile işaretli; dermisi tamamen dolduran köpüksü histiyositlerin bulunduğu alanlar yıldız ile işaretli) (H\&E, x40). b. Papiller dermisi tamamen dolduran yuvarlak nükleuslu, geniş köpüksü sitoplazmalı, atipi ve mitoz içermeyen köpüksü histiyositler (yıldız ile işaretli) ile epidermis yüzeyinde hiperkeratoz ve parakeratoz ile beraber nötrofil lökosit infiltrasyonu (ok ile işaretli) (H\&E, x200). c. Köpüksü histiyositlerde yaygın olarak izlenen sitoplazmik CD68 pozitifliği (CD68 antikoru, x200).

Histopatolojik incelemede VK'nin ayırıcı tanısında verruka vulgaris, kondiloma aküminatum, granüler hücreli tümör, skuamöz hücreli karsinom ve verrüköz karsinom yer almaktadır (1,6). Köpüksü makrofajlar verrusiform ksantom tanısı için en önemli karakteristik ayırıcı özellik olsa da detaylı ve dikkatli bir histopatolojik inceleme yapılmalıdır. Granüler hücreli tümörde izlenen granüllü makrofaj benzeri hücreler, verrusiform ksantomda görülen köpüksü makrofajlardan farklı olarak PAS pozitif granüllere sahiptirler ve de derin dermise kadar uzanırlar. Oysa VK'de lezyon genellikle papiller dermiste sınırlıdır (1). Sunulan olguda papiller dermiste sınırlı köpüksü histiyositler PAS histokimyası ile boyanma göstermemişlerdir. Kondiloma aküminatumda görülen 
koilositik hücreler VK'de izlenmez. Yine köpüksü makrofajlar verrüköz karsinomda görülmezler. Skuamöz hücreli karsinomda izlenen bazal membran kaybı ve stromal invazyon ile hücre atipisi de mutlaka ekarte edilmelidir. Bunun hem VK tanısı koyabilmek için, hem de henüz literatürde bildirilmese de VK'den gelişebilecek olası skuamöz hücreli karsinomu ya da verrüköz karsinomu dışlayabilmek için gerekli olduğunu düşünmekteyiz.

VK etyopatogenezi hala net olarak açıklanamamaktadır. Tekrarlayan kutanöz travma, lokal irritasyon ve inflamatuar hastalıklara ikincil epidermiste başlayan dejeneratif değişiklikler sonucunda dejenere keratinositlerden salınan kemotaktik sitokinlerin papiller dermiste köpüksü makrofaj birikimine yol açabileceği ve bu lezyonun gelişimine neden olabileceği ileri sürülmüştür $(2,3,6)$. Ayrıca epiteliyal yüzeyde yerleşen bakteri kolonileri, mantarlar ve HPV gibi mikroorganizmaların da bu lezyonun oluşumuna neden olabilecek hücresel değişikliklere yol açabileceği düşünülmüştür. Literatürde birkaç sunumda VK'lerde HPV pozitifliği bildirilmektedir (1). Ancak bu sunumda sunulan lezyonda ve literatürdeki bazı sunumlarda da HPV negatif olarak bulunmuştur (3, 6). HPV virüsüne yaygın olarak rastladığımızı göz önüne alırsak pozitif sonuçların tamamen tesadüfi olabileceği de akla gelmektedir $(2,6)$. Literatürde VK tanısı alan bazı olgularda ise parakeratotik tabakada PAS ile boyanan Candida albicans mikroorganizması gösterilmiştir (7). Bu sunumda sunulan hastanın hikayesinde, eşinde sık tekrarlayan vajinal kandida enfeksiyonu öyküsü olması nedeniyle biz de lezyondan hazırlanan kesitlerde PAS histokimyası çalıştık. Ancak H\&E boyalı kesitlerde şüpheli görünen ya da PAS histokimyası ile boyanan mantar hifa ya da sporuna rastlayamadık. Diğer bir yandan verrusiform ksantomun lipid metabolizma bozukluğuyla ilişkili olmadığı bilinmektedir (2).

Ide ve ark. (8) oral mukoza yerleşimli verrusiform ksantomlu olgular üzerinde yaptıkları çalışmada köpüksü hücrelerinde immünohistokimyasal olarak makrofaj scavenger reseptör-1, monosit kemoatraktan protein-1, CCR2, HLA-DR ve okside LDL antikoru ile boyanma saptanmıştır. Ayrıca elektron mikroskopik incelemede köpüksü hücrelerin içinde değişen derecelerde lipid ve dense granüler materyal içeren lizozomal ve nonlizozomal sitoplazmik inklüzyonlar görülmüştür. $\mathrm{Bu}$ lezyonun oluşmasında tetikleyici faktörlerin sonucunda MCP-1/CCR2 aracılı makrofaj temini ve sonrasında lezyonda biriken makrofajlarda lizozomal lipid birikimi olduğu gösterilmiştir.

VK'nin tedavisi cerrahi eksizyondur (4). Literatürde skrotumda yerleşim gösteren VK olgularında rekürrens bildirilmemiştir. Bu sunumda sunulan olguda 4 yıl 10 aydır lezyon tekrarı olmadan sağlıklı yaşamına devam etmektedir. VK gibi papiller ve verrüköz görünüme sahip lezyonların histopatolojik tanısı, geniş rezeksiyondan kaçınmak için ve hastaların takipleri açısından oldukça önemlidir. Bu olgu, yerleşim yeri olarak oldukça nadir görülmesi, makroskopik olarak malign lezyonlar ile karışabilmesi ve tanısının mutlaka histopatolojik inceleme ile konulması gerektiğinden sunulmaya değer bulunmuştur.

\section{Kaynaklar}

1. Khaskhely NM, Uezato $\mathrm{H}$, Kamiyama $\mathrm{T}$, et al. Association of human papillomavirus type 6 with a verruciform xanthoma. Am $\mathrm{J}$ Dermatopathol 2000;22(5):447-52.

2. Cumberland L, Dana A, Resh B, Fitzpatrick J, Goldenberg G. Verruciform xanthoma in the setting of cutaneous trauma and chronic inflammation: Report of a patient and a brief review of the literature. J Cutan Pathol 2010;37(8):895-900.

3. Kanitakis J, Euvrard S, Butnaru AC, Claudy A. Verruciform xanthoma of the scrotum in a renal transplant patient. Br J Dermatol 2004;150(1):161-3.

4. Philipsen HP, Reichart PA, Takata T, Ogawa I. Verruciform xanthoma-biological profile of 282 oral lesions based on a literature survey with nine new cases from Japan. Oral Oncol 2003;39(4):325-36.

5. Val-Bernal JF, ArguetaL Val D, González-Vela MC, Garijo MF. Verruciform xanthoma is another condition associated with pseudoepitheliomatous hyperplasia. Am J Dermatopathol 2012;34(3):341-2.

6. Erşahin C, Szpaderska AM, Foreman K, Yong S. Verucciform xanthoma of the penis not associated with human papilloma virus infection. Arch Pathol Lab Med 2005;129(3):e62-4.

7. Mostafa KA, Takata T, Ogawa I, ljuhin N, Nikai H. Verruciform xanthoma of the oral mucosa: A clinicopathological study with immunohistochemical findings relating to pathogenesis. Virchows Arch A Pathol Anat Histopathol 1993;423(4):243-8.

8. Ide F, Obara K, Yamada H, Mishima K, Saito I, Kusama K. Cellular basis of verruciform xanthoma: Immunohistochemical and ultrastructural characterization. Oral Dis 2008;14(2):150-7. 